\title{
Introduction to Problem Solving Based Learning Model
}

\author{
Tanwey Gerson Ratumanan ${ }^{1, *}$ Carolina S. Ayal ${ }^{2}$
}

\author{
${ }^{1,2}$ Mathematics Education, Univesity of Pattimura \\ *Corresponding author. Email: gratumanan@gmail.com
}

\begin{abstract}
Studies on innovative learning model are currently being carried out by experts to contribute to improving the quality of education and learning. Problem Solving Based Learning Model (PBPM) is one of the new model that the author has developed since 2017-2020. From the development results, this model is considered to meet the quality requirements of a learning model, namely meeting the aspects of validity, practicality, and effectiveness. The syntax of the PBPM model consists of 7 stages (phases), namely (1) introduction, (2) discussion of material, (3) problem solving, (4) presentation and discussion, (5) expansion of problem solving, (6) presentation and discussion ( continued), and (7) closing. With a focus on problem solving, especially in phase 5, where the problems presented are complex problems, including problems presented in an open-ended form, will stimulate the development of problem-solving abilities, higher-order thinking, and creative thinking. The fourth and sixth phases, namely presentations and discussions, will not only improve understanding of mathematics material, but also develop mathematical communication skills. Furthermore, the problemsolving process carried out in small groups cooperatively will have an impact on the development of cooperation capabilities and acceptance of diversity.
\end{abstract}

Keywords: Problem Solving, Based Learning Model.

\section{INTRODUCTION}

Education in the 21st century is faced with more complex competency demands. School education is no longer sufficient if it is directed to equip students with a variety of subjects designed in the curriculum. School education must also function to develop the potential of graduates optimally and equip graduates to continue their studies to a higher level including college and to survive in real life and in the world of work.

Mastery of concepts and skills is indeed an important aspect of education, but this ability is not sufficient to equip students to survive in life. School education must also be directed to build broader abilities, such as critical thinking and creative thinking skills, independent learning skills, innovation abilities, mastery of informatics technology, etc. [1]. The ability to think, including higher-order thinking, is an important ability that needs to be developed. Development of higher order thinking skills is currently the main goal of education $[2,3]$; teachers should develop students' higher order thinking skills needed to face new challenges [4]. Teachers should have various strategies in the teaching and learning process, especially when implementing higher-order thinking [5].

Wagner [6], describes 7 (seven) skills needed by students in the 21 st century, namely (1) critical thinking and problem solving, (2) collaboration and leadership, (3) agility and adaptability, (4) initiative and entrepreneurship, (5) effective oral and written communication, (6) accessing and analyzing information, and (7) curiosity and imagination. Fadel [7] and Bishop [8] describe the 21st century skills framework. , includes:

a. Core subjects, consisting of (1) native / reading languages, (2) world languages, such as English, (3) arts, (4) geography, (5) history, (6) mathematics, (7) science, (8) citizenship.

b. 21st century themes, consisting of (1) global awareness, (2) financial, economic, business and entrepreneurial literacy, (3) legal literacy, (4) health literacy, and (5) environmental literacy;

c. Information proficiency, media and technology, consisting of liracy information, media, and ICT; 
d. Life skill and career, consisting of (1) flexibility and adaptability, (2) initiative and self direction, (3) social skills and cross-cultural, (4) productivity and accountability, and (5) leadership and responsibility;

e. Learning skills and innovation consist of (1) critical thinking and problem solving, (2) communication, (3) collaboration, and (4) creativity.

The current problem shows that these 21st century skills have not been able to be developed properly in the world of education, both in schools and colleges. Various research results indicate that there are fundamental weaknesses related to these skills. Mastery of the indirect object of mathematics which includes the students' problem solving and reasoning abilities is relatively low [9]; Many students' high-order thinking skills are relatively low $[10,11,12,13]$.

This problem shows that there is something that is not optimal in the education system in Indonesia. Is it related to curriculum structure, quality of learning, quality of assessment, or other factors. The quality of learning should be assumed as one of the components that makes a big contribution to the inability of students to achieve the 21 st century competence. The results of Ratumanan and Tetelepta's research (2019) show that there are still weaknesses in learning, including (1) the average score of RPP mathematics at SMA Negeri 1 Masohi is 67.01 and is in the sufficient category, (2) The teacher has not been able to manage learning in a manner good. Although in the lesson plan the teacher plans to use a variety of student centered learning models with a scientific approach, but in the implementation of learning, there is still a tendency for teachers to dominate learning by transferring knowledge. the knowledge construction process is not considered, and (3) the learning outcome assessment activities cannot be implemented properly and structured. The teacher does not prepare instruments for the assessment of knowledge, attitudes and skills. The teacher conducts attitude assessment in general by only observing student activities, both class activities and group activities, without using the observation format, and (4) teachers pay less attention to material enrichment and high order thinking. Mathematical problems that are given to students to be done both individually and in groups, are more focused on aspects of understanding (C2) and applications (C3), (3) The ability to use communication and information technology in learning is still relatively limited.

Currently schools in Indonesia have implemented the 2013 curriculum that places students as subjects in learning. Various innovative learning models are currently being developed to contribute to improving the quality of learning. In this connection, the researcher develops a new learning model called "Problem Solving Based Learning Model". This model was developed by the author from 2017-2020. From the results of the development and limited experiments, this model is considered to meet the quality requirements of a learning model, namely meeting the aspects of validity, practicality, and effectiveness.

Problem-solving based learning models emphasize problem solving activities in a structured manner from easy to difficult, from simple to complex.

The existence of this problem-solving activity process is expected to stimulate students' thinking processes, so that gradually their thinking skills can develop. This paper will further discuss this new model which is expected to be an alternative model for innovative learning in schools and colleges.

\section{SYNTAX OF PROBLEM SOLVING BASED LEARNING MODEL}

The problem-solving learning model was developed in 2 (two) stages of research, that is the development stage and the experimental stage for testing the effectiveness of the model. From the research process for two stages in two years, a learning model was produced called a problem-solving based learning model. The problem-solving based learning model (PBPM model) was developed consisting of 5 (five) important components, namely (1) syntax, (2) social systems, (3) reaction principles, (4) support systems, and (5) instructional impact and accompaniment impact.

Syntax refers to the entire flow or sequence of teaching and learning activities. The syntax specifies the types of teacher and student actions required, their order and the assignments for students. Syntax is described in a sequence of activities called phases, each learning model has a different phase flow [14]. The social system states the roles and relationships of students and the types of norms recommended. The role of teacher leadership varies greatly from one model to another [14]. Reaction principles are related to how teachers pay attention to and treat students, including how teachers respond to answer questions, responses or what students do. The support system (support system) of a learning model is all the means, materials and tools needed to implement the model [15]. The instructional impact is the learning outcomes that are achieved directly by directing students to the expected goals, for example student mastery of material X ". Meanwhile, the accompanying impact is other learning outcomes produced by a teaching and learning process, as a result of creating a learning atmosphere that is experienced directly by students without direct guidance from the teacher [15].

Specifically regarding the syntax of the problem solving-based learning model (PBPM) the results of the development are presented in the following table 
Table 1. Syntax of Problem Solving Based Learning Model

\begin{tabular}{|c|c|}
\hline Phase & Description \\
\hline 1. Introduction & $\begin{array}{l}\text { This phase is the initial learning activity in the form of greetings, delivery of learning } \\
\text { objectives, perceptions, motivation, and organizing students to learn. Students are } \\
\text { divided into small groups of 3-5 people. }\end{array}$ \\
\hline 2. Discussion of the Material & $\begin{array}{l}\text { In this phase, the learning material is studied or discussed. The teacher can present the } \\
\text { main points of the material briefly. In this phase, knowledge can also be constructed by } \\
\text { students by studying teaching materials that have been prepared by the teacher or by } \\
\text { studying teaching materials in textbooks or on certain websites. Teachers need to } \\
\text { encourage students to ask questions about parts of the material that are not well } \\
\text { understood. The teacher needs to provide a limited explanation of each student's } \\
\text { question. It is important to note that teachers should avoid the habit of transferring } \\
\text { knowledge in the form of explaining learning materials at length. }\end{array}$ \\
\hline 3. Problem Solving Activities & $\begin{array}{l}\text { Relevant problems are given for each group to solve. Problems are given at a simple } \\
\text { and moderate level. From the cognitive aspect, the problems given are problems at } \\
\text { levels C2 and C3. When the group works, the teacher goes around supervising and } \\
\text { providing support to the group. }\end{array}$ \\
\hline $\begin{array}{l}\text { 4. Presentation } \\
\text { discussion }\end{array}$ & $\begin{array}{l}\text { Randomly, the teacher appoints certain groups to present or write down the results of } \\
\text { their work on the board. The results of small group work are discussed in large groups. } \\
\text { In this phase, the teacher also provides confirmation, in the form of clarification, reward, } \\
\text { expansion, deepening, etc. }\end{array}$ \\
\hline $\begin{array}{l}\text { 5. Expansion of problem } \\
\text { solving }\end{array}$ & $\begin{array}{l}\text { The teacher provides more complex problems, students do it in small groups. The } \\
\text { problems presented in this phase are related to higher order thinking (HOT) and creative } \\
\text { thinking. From the cognitive aspect, the problems presented in this phase are problems } \\
\text { in levels } \mathrm{C} 4, \mathrm{C} 5 \text {, and } \mathrm{C} 6\end{array}$ \\
\hline $\begin{array}{l}\text { 6. Presentation } \\
\text { discussion }\end{array}$ & $\begin{array}{l}\text { The teacher randomly assigns groups to write down the results of their work on the } \\
\text { board or present them to the class. The results of group work are discussed in large } \\
\text { groups. In this phase, the teacher also provides confirmation, in the form of clarification, } \\
\text { reward, expansion, deepening, etc. }\end{array}$ \\
\hline 7. Closing & $\begin{array}{l}\text { The teacher and students make summaries, give assignments, and give tests (if it was } \\
\text { planned from the start). }\end{array}$ \\
\hline
\end{tabular}

\section{EXAMPLE OF APPLICATION OF PROBLEM SOLVING BASED LEARNING MODEL}

Learning using the PBPM model places students as subjects in teaching and learning activities. Teachers are more of a role as facilitators and motivators who facilitate and motivate students to learn. In learning activities, the teacher only provides a brief explanation of the learning material in phase 2, then learning activities and problem solving are carried out by students in phase 3 and phase 5. The activities in these two phases are not only useful for increasing understanding of concepts, principles, and skills, but also for improving students' higher order thinking skills. In these two phases, students solve problems in small groups, discuss, share with each other, help each other complete group assignments. This will have an impact on increasing the ability of students to cooperate. In the 4th and 6th phases, students present their work and discuss in large groups. There is a process of sharing between groups, but it is also possible for the emergence of criticism and new questions that stimulate the thinking processes of students. The confirmation given by the teacher in this phase will strengthen students' understanding of the material discussed [1].

The following is an example of learning the material "Derivative Applications" using the PBPM model. The learning phases are as follows:

a. Introductory Phase 
The teacher explains the learning objectives and benefits that will be obtained by students after participating in learning, namely that students are able to use derivative functions in solving various relevant problems, including (1) determining maximum and minimum values, and (2) solving problems of speed and acceleration. As an apperception, the teacher can briefly remind students about the first and second derivative tests to determine the type of extreme.

The teacher organizes students in small groups of 3-5 people, the sitting positions of each group are arranged in such a way as to allow mutual eye contact between each members of the group.

\section{b. Material Discussion Phase}

The teacher distributes teaching materials to each group, which contains a description of the material and student worksheets. If the teacher does not develop teaching materials, the teacher can ask students to open the Class XI Mathematics textbook [16]. The teacher explains the properties of the extreme point in terms of the first derivative and the second derivative, briefly. For example, the teacher displays the following slides and provides a brief explanation.

Let fbe a continuous real-valued function having the first and second derivatives of $x i \in I$ such that:

1) If $f^{\prime}\left(\mathrm{x}_{\mathrm{i}}\right)=0$, then the point $\left(\mathrm{x}_{\mathrm{i}}, \mathrm{f}\left(\mathrm{x}_{\mathrm{i}}\right)\right)$ is called the stationary point or critical point

2) If $f^{\prime}\left(\mathrm{x}_{\mathrm{i}}\right)=0$, and $f^{\prime}\left(\mathrm{x}_{\mathrm{i}}\right)>0$, then the point $\left(\mathrm{x}_{\mathrm{i}}, \mathrm{f}\left(\mathrm{x}_{\mathrm{i}}\right)\right)$ is called the minimum point of the function.

3) If $f^{\prime}\left(\mathrm{x}_{\mathrm{i}}\right)=0$ and $f^{\prime}\left(\mathrm{x}_{\mathrm{i}}\right)<0$, then the point $\left(\mathrm{x}_{\mathrm{i}}, \mathrm{f}\left(\mathrm{x}_{\mathrm{i}}\right)\right)$ is called the maximumpoint of the function.

4) If $f^{\prime}\left(\mathrm{x}_{\mathrm{i}}\right)=0$, then the point $\left(\mathrm{x}_{\mathrm{i}}, \mathrm{f}\left(\mathrm{x}_{\mathrm{i}}\right)\right)$ is called the inflection point

The teacher then assigns students to study the material provided in teaching materials or in textbooks and discuss with their respective groups. If there is material that is poorly understood, the teacher develops a class discussion to discuss the material, if there are no students or groups who can provide solutions, the teacher can provide a brief explanation.

\section{c. Problem Solving Phase}

In this phase, the teacher displays questions or problems for students to work on in small groups. The problems presented are at the level of understanding (C2) and application (C3), with easy and moderate difficulty levels for each group to work on. The focus of this problem presentation is so that students can understand the concept or subject matter better and be able to apply concepts, principles, or procedures in solving problems. The problems presented should be included in the student worksheet (LKPD). For example the problem is as follows:
1) Attention to function $f(x)=2 x^{3}-9 x^{2}-24 x+32$. Specify

a. Stationary point

b. Maximum or minimum point

c. inflection point

2) An object moves along a straight line. The equation for the motion of the object is $s=f(t)=t^{3}-6 t^{2}+$ $9 t$; $(s$ in meters and $t$ in seconds),

a. Calculate the object's velocity at $\mathrm{t}=1$ second

3) Calculate the object's acceleration at $t=1$ second

In dealing with both of these problems, the group may experience difficulties. Therefore, the teacher needs to go around visiting each group to observe the work process of each group. The teacher needs to encourage each group to discuss and share with each other to jointly solve the problem. If the group experiences problems related to mastery of concepts, the teacher can provide a brief explanation to be able to guide students in solving these problems.

\section{d. Presentation and Discussion Phase}

In this phase, the teacher appoints a certain group to write down the solution on the white board and provide an explanation. Appointment of groups can be done randomly or can also be based on teacher observations of the progress of group work. After the designated groups explain their work, the teacher facilitates a class discussion by giving other groups the opportunity to ask questions, provide comments, or compare the results of their group work. At the end of the discussion, the teacher provides confirmation in the form of clarification, reward, or additional explanation to expand or deepen the concept.

\section{e. Expansion of Problem Solving Phase}

This phase is an advanced phase of the third phase. Teachers provide more complex problems that demand analysis (C4), synthesis (C5), or evaluation (C6) processes. The problem can be presented on the presentation slide or already presented on the student worksheet. For example, the problem is as follows: 
1) An object moves along a straight line. The equation for the motion of the object is $s=f(t)=t^{3}-$ $12 t^{2}+45 t ; ;(s$ in meters and $t$ in seconds),

a. Determine at which intervals the object's velocity increases and at which intervals the object's velocity decreases.

b. Determine at which interval the object's acceleration increases and at which interval the object's acceleration decreases

2) A box without a lid is made from a cardboard measuring $60 \mathrm{~cm} \times 40 \mathrm{~cm}$, by cutting identical (equivalent) squares on the four corners, and folding the sides. Determine the length, width, and height of the box for maximum volume.

It is expected that in the fourth phase, students have an adequate understanding of the application of derivative functions in solving relevant problems. With this understanding, it is hoped that through group discussions and mutual variety, students can develop their thinking skills to solve more complex problems. The second problems above are more complex and require a higher thought process when compared to the problems in the third phase. To work on problem number 1, students must have the ability to use the rules of derived functions and relate them to the concepts of speed and acceleration. Furthermore, to work on question number 2 , students must have the ability to identify the context of the problem, determine the formula for the volume of the box, and then use derived rules to determine the size of the length, width and height of the box. In dealing with both of these problems, the group may experience difficulties. Therefore, as in the third phase, teachers need to go around visiting each group to observe the work process of each group, and provide limited assistance to groups experiencing difficulties.

\section{f. Presentation and Discussion Phase}

Similar to the fourth phase, in this phase, the teacher appoints certain groups to write their solutions on the white board and provide explanations. The teacher then facilitates the class discussion by giving other groups the opportunity to ask questions, provide comments, or compare the results of their group work. At the end of the discussion, the teacher provides confirmation in the form of clarification, reward, or additional explanation to expand or deepen the concept.

\section{g. Closing Phase}

In this phase, the teacher directs students to provide a summary of the derivative function application material. Teachers should prepare assignments for students to do at home in an effort to increase students' mastery and retention of learning materials

\section{COMPETENCY DEVELOMPMENT THROUGH THE APPLICATION OF PROBLEM SOLVING BASED LEARNING MODEL}

Learning mathematics using the PBPM model is expected to have a positive impact on the development of students' competencies. Some of the capabilities that are expected to be developed are as follows:

a. Mastery of learning material

Learning activities in phase 2 to phase 6 allow students' mastery of teaching materials to be much better when compared to conventional learning. In the PBPM model, students are actively involved in the learning process. This is very influential on the level of memorization of students, knowledge in the form of mathematical material will be better mastered, and stored longer in the memory of students. In the 3rd and 5th phases, there is a process of sharing and the development of peer tutors, weak students will ask questions and learn from smart students; on the contrary, smart students will help provide explanations for weak students. Process is effective for increasing students' mastery of learning material. According to [17], by working together, helping each other, and contributing to each other's thoughts, it is hoped that the teaching materials that are learned or discussed in groups can be better understood, compared to when studied individually.

\section{b. Problem solving skill}

In phases 3 and 5, students work together in small groups to solve math problems ranging from simple to complex. In the 3rd phase there are still routine questions, but these questions are completed with non-routine questions or problems. In the fifth phase, the problems presented are more complex and require higher thinking. By carrying out problem-solving activities continuously in groups, gradually the problem-solving abilities of students will increase.

\section{c. Higher order thinking skills}

Learning using the PBPM model stimulates the thinking process of students. All phases, especially phases 2 to 6 require the involvement of students mentally in the learning process. In phases 2 and 3, thinking activities are still limited to low and middle level thinking (knowledge, understanding, and application of mathematical concepts or principles). In the fifth phase, namely the expansion of problem solving, students are faced with more complex problems; the teacher provides problems that are formulated in the category of analysis, synthesis, or evaluation; or when referring to Bloom's taxonomy as revised by Anderson \& Krathwhol [18], it is formulated in the category of analyzing, evaluating, and creating. To solve problems 1 and 2 in phase 5 above, for example, students not only have to understand the concept and be able to apply it, but students also need to 
make connections between concepts or between principles, and analyze these relationships. Problem 2, for example, students need to first do a visualization, make an identical square (the same square) on the four corners of the cardboard, let the side lengths be $\mathrm{x}$, cut the identical rectangles, fold the cardboard so that it forms a box without a lid, with length $=(60-2 \mathrm{x}) \mathrm{cm}$, width $=(40$ $2 \mathrm{x}) \mathrm{cm}$, and height $=\mathrm{x} \mathrm{cm}$. Furthermore, students use the formula for the volume of the cube, and use the derivative rule to get $x$. The final step, students substitute the value of $\mathrm{x}$, to find the length, width, and height of the box. In this problem solving step, students do not just apply concepts or principles, but must use a more complex or higher thought process, namely analyzing the relationship between rules.

In the 4th and 6th phases, in percentages and discussions, questions or criticisms that demand students' reasoning can also develop. Questions "why", "how", "is there another way", etc. can arise from students and teachers to groups that present their assignments.Questions like this, not only stimulate students to think more carefully and comprehensively, but also think more critically. Thus, the implementation of the PBPM model will gradually function effectively to improve the higher order thinking skills of students.

\section{d. Ability to think creativity}

In the fifth phase, the problem can also be presented in an open-ended form. Open ended problem is an open problem that has more than one alternative to the correct answer. [19], classify open problems into three types, namely: (1) problems that can be solved in various ways, (2) problems that have varied answers, and (3) problems that can be developed by changing the conditions of the previous problem.Presentation of open-ended problems in the fifth phase of the PBPM model will encourage students to think of various ways to solve problems. Conditions like this in the long run will be able to develop the thinking skills of students.

\section{e. Collaboration}

The ability to work together is an important ability that helps determine a person's success in life and at work. The ability to cooperate contains many other abilities such as the ability to share each other, the ability to listen with empathy, the ability to accept and appreciate differences, the ability to convey differences of opinion in an acceptable way, the ability to communicate politely, etc. These abilities can grow and develop in learning using cooperative settings. The PBPM model uses a cooperative setting in learning. In phases 3 and 4 in small groups of students work together to complete group assignments in the form of problem solving. In phases 4 and 6 , each group presents its work and shares it with one another. This kind of learning setting will be able to develop the cooperation ability of each student.

\section{f. Mathematical Communication Skills.}

Mathematical communication is an important aspect that needs attention in learning mathematics. Communication in mathematics is one of the other common basic skills, namely reasoning skills and problem solving abilities (NTCM, 2000). Mathematical communication is meant here are interconnected events where there is delivery and reception of mathematics messages in a classroom environment.Mathematical messages here relate to the mathematical material that students are studying in teaching and learning activities [17]. In learning mathematics using the PBPM model, students are also directed to be able to explain the thinking process and the results of problem solving they get. Conversely, other students are expected to respond by making corrections with logical arguments against the results of knowledge construction and problem solving. By carrying out this kind of process continuously, it can be expected that the students' mathematical communication skills can improve.

g. Positive attitude towards mathematics.

In the PBPM model, students are actively involved in teaching and learning activities, both in learning teaching materials and in problem solving activities. Learning activities are dynamic and fun. This condition results in the impression that mathematics is a difficult subject, even scary, can be changed gradually. Thus learning mathematics using the PBPM model will also be able to foster a positive attitude towards mathematics.

\section{CONCLUSION}

Problem-solving based learning model (PBPM Model) is a new model developed as an alternative model.Through the application of this model, it is hoped that various abilities of students can be developed including mastery of teaching materials, problem solving abilities, higher order thinking skills, creative thinking, collaboration, mathematical communication skills, and positive attitudes towards mathematics.

As a newly developed model, so far there has not been much information about the effect of the PBPM model on student competency development. In connection with this, it is hoped that this model can be studied further and can be used as an alternative model for student competency development.

\section{REFERENCES}

[1] Ratumanan, T. G., \& C. S. Ayal. (2018). Problem Solving Based Learning ModelAlternative Model of Developing High Order Thinking. International Journal of Health Medicine and Current Research (IJHMCR) Vol. 3, Issue 02, June, 2018, pp.857-865. 
[2] Fisher, R. (1999). Thinking skills to thinking schools: Ways to develop children's thinking and learning. Early Child Development and Care, 153, 51-63. Retrieved from http://ezproxy.um.edu.my:2077/doi/pdf/10.1080/03 00443991530104.

[3] Zohar, A., \& Schwartzer, N. (2005). Assessing teachers' pedagogical knowledge in the context of teaching higher-order thinking. International Journal of Science Education, 27(13), 1595-1620.

[4] Heong, Y. M., Othman, W. B., Yunos, J. Bin, Kiong, T. T., Hassan, R. Bin, Mohaffyza, M., \& Mohamad, B. (2011). The Level of Marzano Higher Order Thinking Skills among Technical Education Students. International Journal of Social Science and Humanity, 1(2), 121-125.

[5] Indriyana, Bernadeta Siska., \& Kuswandono, Paulus. (2019). Developing Students' Higher Order Thinking Skills (HOTS) in Reading: English Teachers' Strategies in Selected Junior High Schools. Journal of English Teaching, Volume 5 (3), October 2019, pp. 204-216.

[6] Saavedra, Anna Rosefsky Saavedra and Opfer, Darleen. (2012). Teaching And Learning 21st Century Skills: Lessons From The Learning Sciences. Asia Society, Partnership for Global Learning.

[7] Fadel, Charles. 2008. 21st Century Skills: How can you prepare students for the new Global Economy? Paris: OECD/CERI https://www.oecd.org/site/educeri21st/ 40756908.pdf. (diakses 8 September 2018)

[8] Bishop, Joseph. 2010. Partnership for 21st Century Skills (P21). https:/www.imls.gov/ assets/1/ AssetManager/Bishop\%20Pre-Con\%202.pdf. (diakses 8 September 2018).

[9] Ratumanan, T. G., \& Theresia Laurens. (2016). Analisis Penguasaan Objek Matematika (Kajian pada Lulusan SMA di Provinsi Maluku). Jurnal Pendidikan Matematika Raflesia, Vol 1, No 2 Desember 2016, hal. 146-154.

[10] Kurniati, Dian., Romi Harimukti., \& Nur Asiyah Jamil. (2016). Kemampuan Berpikir Tingkat Tinggi Siswa SMP di Kabupaten Jember dalam Menyelesaikan Soal Berstandar PISA. Jurnal Penelitian dan Evaluasi Pendidikan Volume 20, No 2, Desember 2016 (142-155).

[11] Prasetyani, Etika., Yusuf Hartono., dan Ely Susanti. (2016). Kemampuan Berpikir Tingkat Tinggi Siswa Kelas XI dalam Pembelajaran Trigonometri Berbasis Masalah di SMA Negeri 18 Palembang.
JURNAL GANTANG Pendidikan Matematika FKIP - UMRAH Vol. 1 No. 1, Agustus 2016, 31-40.

[12] Purbaningrum, Kus Andini. (2017). Kemampuan Berpikir Tingkat Tinggi Siswa SMP dalam Pemecahan Masalah Matematika Ditinjau dari Gaya Belajar. JPPM Vol. 10 No. 2 (2017), hal. 40-49.

[13] Sucipto. (2017). Pengembangan Ketrampilan Berpikir Tingkat Tinggi Dengan Menggunakan Strategi Metakognitif Model Pembelajaran Problem Based Learning. Jurnal Pendidikan Volume 2 Nomor 1 Tahun 2017, hal. 63-71.

[14] Joice, Bruce, Marsha Weil, and Calhoun. 2009. Models of Teaching. Boston: Pearson Education, Inc.

[15] Ratumanan, T. G. (2003). Pengembangan Model Pembelajaran Interaktif dengan Setting Kooperatif (Model PISK) dan Pengaruhnya Terhadap Hasil Belajar Matematika Siswa SLTP Di Kota Ambon. Disertasi. Surabaya: Program Pascasarjana Universitas Negeri Surabaya.

[16] Manullang, Sudiyanto., Andri Kristianto S., \&Tri andri Hutapea. (2017). Matematika SMA/MA/SMK Kelas XI. Jakarta: Kementerian Pendidikan dan Kebudayaan.

[17] Ratumanan, T. G. (2016). Inovasi Pembelajaran. Bandung: Alfbeta.

[18] Anderson, O. W. \& Krathwohl, D.R. 2001. A Taxonomy for Learning Teaching, and Assessing (A Revision of Blooms Taxonomy of Educational Objectives). New York: Addision Wesley, Longman.

[19] Putri, Octavina Rizky Utami. (2017). Pengembangan Buku Siswa Bercirikan Open Ended Mathematics Problem Untuk Membangun Berpikir Kreatif. Jurnal Silogisme: Kajian Ilmu Matematika dan Pembelajarannya Juni 2017, Vol. 2, No.1, 7-14. 